\title{
Activation of Soil Microflora by Fungus Spores in Relation to Soil Fungistasis
}

\author{
By B. T. LINGAPPA* AND J. L. LOCKWOOD \\ Department of Botany and Plant Pathology, Michigan State University, \\ East Lansing, Michigan, U.S.A.
}

(Received 29 October 1963)

\section{SUMMARY}

Bacterial numbers in natural soil supplemented with living fungus spores or cell-free aqueous washings of spores, then incubated for $8 \mathrm{hr}$ or more, were several-fold higher than those in non-supplemented soil. Rates of oxygen uptake in natural soil supplemented with washed or unwashed fungus spores, cell-free aqueous washings of spores, killed spores, or diluted nutrients, were several-fold higher than those in non-supplemented soil. Increased respiration occurred rapidly on addition of these supplements to soil. A single brief water washing of urediospores of Puccinia rubigo-vera or of conidia of Neurospora sp. extracted about $10 \%$ of the spore dry weight. Washed bacteria or Streptomyces spp., when incubated with fungus spores in absence of added nutrients, inhibited fungus spore germination, whereas sterile filtrates of bacteria were not inhibitory. The results indicate that fungus spores, by virtue of nutrients in their exudates, stimulate rapid activity of microbes in soil, and that the enhanced microbial activity causes inhibition of fungal spore germination.

\section{INTRODUCTION}

The cause and nature of the widespread soil fungistasis (mycostasis) are not yet clearly understood. The usual explanation proposed for inhibition of fungus spore germination by natural soils is the presence therein of unstable fungistatic materials of microbial origin (Dobbs, Hinson \& Bywater, 1960). Park (1961) and Griffin (1962 $a$ ) suggested that these materials might be analogous with staling-products of cultures. Nevertheless, the presence of such materials in soil has not been unequivocally demonstrated. Lingappa \& Lockwood (1961) offered evidence, based primarily on an analysis of the mechanism of fungistasis on agar dises or cellophan in contact with soil, that inhibitory substances might not be present throughout the soil mass, but might be generated in the vicinity of fungus spores by soil microbes activated by compounds exuded from the spores. The present report provides evidence that fungus spores and spore exudates can rapidly stimulate the soil microflora, and that microbial stimulation is causally related to inhibition of fungal spore germination. A brief report of some of this work has been published (Lingappa \& Lockwood, 1962).

* Present address : Department of Biology, College of the Holy Cross, Worcester, Mass., U.S.A. 


\section{METHODS}

Conidia of Glomerella cingulata, Fusarium solani f. pisi, Helminthosporium victoriae, and Neurospora sp.; and urediospores of Puccinia graminis tritici and of $P$. rubigo-vera were used to supplement natural soil samples. Conidia of G. cingulata, $F$. solani, and $H$. victoriae were collected by quickly rinsing them from the surface of slopes of potato glucose agar (PGA) with cold $\left(2^{\circ}\right)$ sterile distilled water. Conidia of Neurospora sp. are produced near the top of the test tube above the agar surface, and were collected by tapping the inverted tube. Rust fungi were cultured on Little Club wheat plants in a greenhouse. Spore washings were prepared by shaking spores in $10 \mathrm{ml}$. cold sterile distilled water for $15 \mathrm{~min}$., centrifuging-off the spores, then filtering the solution through $0 \cdot 45 \mu$ Millipore filters or Seitz sterilizing filters. Washings were air-dried, weighed, then brought to the desired concentration by dissolving in distilled water.

The soil used was sifted Conover loam containing $25 \%$ moisture. Supplements per g. oven-dry soil are indicated as fresh weight of rust urediospores or Neurospora sp. conidia, or oven-dry weight of other spores or spore-washings. Urediospores and Neurospora sp. conidia contained 10-15\% moisture. Experiments were repeated two to five times, with reproducible results.

Dilution plates. The desired amounts of spores or spore washings in $0.5 \mathrm{ml}$. distilled water were mixed with $\mathbf{1 . 3}$ g. moist soil in small beakers. After incubation for $2-24 \mathrm{hr}$ at $28^{\circ}$ in a moist atmosphere, dilutions to $1 \times 10^{-6}$ or $1 \times 10^{-7}$ were made in sterile distilled water. One ml. of the final dilution was mixed in a Petri dish with $15 \mathrm{ml}$. melted $\left(43^{\circ}\right) 2 \%$ water agar or sodium albuminate agar containing $100 \mu \mathrm{g}$. cycloheximide/ml. The antibiotic was used to prevent growth of fungi from the supplement. Six plates were used for each treatment. Plates were incubated at $28^{\circ}$ for 7-10 days, when total colony numbers were determined.

Respirometry. Manometric measurements of oxygen uptake by soil were made with a Warburg apparatus and standard procedures (Umbreit, Burris \& Stauffer, 1957). Duplicate $15 \mathrm{ml}$. reaction vessels each contained $2 \cdot 7 \mathrm{~g}$. moist soil. Flasks were placed in ice while $0.4 \mathrm{ml}$. spore suspensions or spore washings were added and mixed with the soil. After $10 \mathrm{~min}$. equilibration of flasks in the water bath at $30^{\circ}$, readings were made at $\mathbf{3 0} \mathrm{min}$. intervals. Data are expressed as $\mu \mathrm{l}$. oxygen uptake/g. soil for each time interval.

Germination inhibition with washed micro-organisms. Samples of the following micro-organisms were used in inhibition tests: Rhizobium trifolii, Bacillus subtilis, two unidentified bacteria designated as isolates G-1 and G-2, four isolates of Streptomyces. A mixed culture of bacteria from soil was also used. Bacterial isolates G-1 and G-2 were obtained from dilution plates made from soil supplemented with Glomerella cingulata conidia, and have the following properties : non-motile straight rods, $0.3-0.4 \mu \times 1.0-3.0 \mu$; do not form spores, Gram-negative, aerobic and nonfermentative. On nutrient agar G-2 produces a light yellow diffusible pigment, whereas G-1 does not. G-1 has a higher temperature optimum than G-2. Both are tentatively placed in the genus Pseudomonas.

Pure cultures of bacteria were grown for 1-2 days, and the Streptomyces isolates for 7 days, on yeast extract + maltose + glucose agar slopes. Then organisms or spores were removed with cold $0.01 \mathrm{M}$-phosphate buffer $(\mathrm{pH} 7 \cdot 2)$. Mixed soil 
bacteria were grown by incubating about $50 \mathrm{mg}$. moist soil in $5 \mathrm{ml}$. nutrient broth for $24 \mathrm{hr}$. The organisms were filtered through Whatman No. 1 paper to remove soil particles. Bacteria and Streptomyces spores were washed three times with cold buffer by vigorous shaking followed by centrifugation. The washed organisms were adjusted in concentration to scale reading 1.0 optical density at $500 \mathrm{~m} \mu$, using a Bausch \& Lomb Spectronic 20 colorimeter standardized with a water blank. Adjusted suspensions of mixed soil bacteria contained about $2 \times 10^{8}$ organisms $/ \mathrm{ml}$. as determined with a haemocytometer; bacterial isolates G-1, G-2, and Rhizobium trifolii contained about $14 \times 10^{8}$ organisms $/ \mathrm{ml}$. The washed suspensions were diluted, usually $1 / 10,1 / 100$ and 1/1000 with cold buffer. Fungus conidia were removed with cold buffer from 2- to 10-day-old cultures on potato glucose agar, centrifuged once, then adjusted with buffer to $5 \times 10^{4}$ or $2 \times 10^{5}$ conidia $/ \mathrm{ml}$.

The inhibitory effect of washed micro-organisms on the germination of fungal spores was tested by incubating dilutions of the bacterial suspensions together with fungus spores in wells of plastic slide plates. Helminthosporium victoriae, Glomerella cingulata or Fusarium solani were tested by mixing $0.1 \mathrm{ml}$. each of conidia and bacterial suspensions. Spores of these three fungi, washed once, germinated well in buffer or distilled water. Mucor ramannianus, Penicillium frequentans or Verticillium albo-atrum were tested by mixing $0.05 \mathrm{ml}$. each of bacterial suspensions and conidial suspension in designated positions on the surface of $2 \%$ Bacto agar (Difco) or $2 \%$ Special agar (Noble; Difco) in Petri dishes. Spores of these fungi germinated poorly in buffer or water, but germinated well on water agar surfaces.

The effect of sterile filtrates of washed microbial suspensions on fungal spore germination was also determined. Filtrates were prepared by passing portions of bacterial suspensions adjusted to 1.0 optical density at $500 \mathrm{~m} \mu$ through sterilized $0.45 \mu$ Millipore filters. Equal volumes $(0.05 \mathrm{ml}$.) of filtrates and fungal spore suspensions were added to wells of slide plates containing conidia of Glomerella cingulata or Helminthosporium victoriae or to water agar surfaces containing conidia of Penicillium frequentans, Verticillium albo-atrum, or Mucor ramannianus. At intervals throughout the germination period the old filtrate in wells of slide plates was replaced with $0.1 \mathrm{ml}$. fresh filtrate from the same bacterial suspensions, incubated at $24^{\circ}$. On agar surfaces, $0.025 \mathrm{ml}$. of fresh filtrate was simply added at intervals since the agar absorbed the liquid. After incubation for 3-5 hr for $\boldsymbol{H}$. victoriae and $16 \mathrm{hr}$ for other fungi, spores and germ tubes were killed and stained with pnenolic rose bengal or methylene blue in lactophenol. Germination counts of at least 200 conidia of each species per treatment were made.

\section{RESULTS}

\section{Population counts in fungal spore-supplemented soil}

In seven tests, natural soil was supplemented with 20-200 mg. $\left(1-4 \times 10^{9}\right)$ conidia of Glomerella cingulata or Neurospora sp., or urediospores of Puccinia graminis. Conidia of $G$. cingulata were not washed and might have carried some nutrients from the culture, but the method of collecting urediospores and the Neurospora conidia eliminated this possibility. Spore-supplemented soil incubated for $16 \mathrm{hr}$ gave three to ten times greater total colony numbers than non-supplemented soil. Greater increases were observed when spore-supplemented soil was incubated 
for $24 \mathrm{hr}$ before plating. Differences were usually greater when soil dilutions were plated on sodium albuminate agar than on water agar. Colony numbers from nonsupplemented natural soil at 0 and $16 \mathrm{hr}$, and spore-supplemented soil at $0 \mathrm{hr}$, did not differ appreciably. Results of a typical experiment with soil supplemented with Neurospora conidia are given in Table 1 . When soils were plated at $0,2,4,8$ and $16 \mathrm{hr}$ following supplementation with Neurospora or $G$. cingulata conidia, the earliest increase in colony numbers occurred at $8 \mathrm{hr}$. For example, soil supplemented with Neurospora conidia, then incubated $8 \mathrm{hr}$, gave a sixfold increase on sodium albuminate agar and a twofold increase on water agar. Analysis of variance was applied to $16 \mathrm{hr}$ data for spore-supplemented and non-supplemented soil, using mean plate counts from different experiments as replicates. Values for spore-supplemented soil were significantly higher (5\% level) than those for nonsupplemented soil.

Table 1. Effect of supplementing natural soil with conidia of Neurospora sp. and incubation for $16 \mathrm{hr}$ on the total numbers of micro-organisms which appeared on dilution plates

Soil was supplemented with $45 \mathrm{mg} .\left(1 \cdot 8 \times 10^{\circ}\right)$ conidia/g. soil, and was diluted $1 \times 10^{-6}$ (water agar) and $1 \times 10^{-7}$ (sodium albuminate agar) for plating. Values are mean of six plates.

\begin{tabular}{|c|c|c|c|c|}
\hline & \multicolumn{4}{|c|}{ Plating medium } \\
\hline & \multicolumn{2}{|c|}{ Water agar } & $\begin{array}{c}\text { Sodium } \\
\text { Colonies/plate }\end{array}$ & nate agar \\
\hline & $0 \mathrm{hr}$ & $16 \mathrm{hr}$ & $\mathbf{0 ~ h r}$ & $16 \mathrm{hr}$ \\
\hline Treatment & & & & \\
\hline $\begin{array}{l}\text { Natural soil } \\
\text { Natural soil + Neurospora } \text { conidia }\end{array}$ & $\begin{array}{l}36 \\
32\end{array}$ & $\begin{array}{r}42 \\
125\end{array}$ & $\begin{array}{l}67 \\
64\end{array}$ & $\begin{array}{r}72 \\
546\end{array}$ \\
\hline
\end{tabular}

Since spore exudates seemed the likely cause of the increased microbial population in spore-supplemented soil, concentrated cell-free aqueous washings of conidia of Fusarium solani and of urediospores of Puccinia graminis were placed, in filter paper dises, on the surface of water agar containing diluted soil suspensions. After $48 \mathrm{hr}$ incubation, in the area surrounding the discs, urediospore washings gave a twofold increase, and conidial washings gave a fivefold increase, in total colony numbers as compared with controls. The colonies were also larger on plates containing spore washings. No inhibition zones were observed as was reported in similar tests with washings from teliospores of Ustilago zeae (Lingappa \& Lockwood, 1961).

Single aqueous washings from urediospores of Puccinia rubigo-vera or Neurospora conidia contained, respectively, $9 \cdot 6$ and $9 \cdot 1 \%$ of the dry weight of the spores. Washings from conidia of Glomerella cingulata contained $14 \%$, and those from Fusarium solani contained $42 \%$ of the spore dry weight, but these might have included solutes from the culture. Ten mg. of $P$. rubigo-vera or Neurospora sp. spore washings were used to supplement $1.3 \mathrm{~g}$. samples of moist soil. Soil dilution plates of water agar, after $16 \mathrm{hr}$ incubation with Neurospora washings, gave a fivefold increase in colony numbers; urediospore washings gave a tenfold increase. The increased numbers of colonies in all experiments were bacterial colonies; actino- 
mycetes decreased. No fungus colonies appeared on plates because of the use of cycloheximide to prevent fungal growth from the supplements. To determine whether spore-sized non-nutritive particles could stimulate microbial development, $1 \cdot 3 \mathrm{~g}$. soil samples were supplemented with $100 \mathrm{mg}$. $\left(2.5 \times 10^{7}\right)$ acid-washed $30 \mu$ diam. glass beads. In three tests no increases in colony numbers were observed in the supplemented soil incubated up to $24 \mathrm{hr}$ before making dilution plates.

These results show that fungus spores added to soil stimulate multiplication of the bacteria in the soil, and suggest that soluble nutrients from the fungal spores cause the stimulation.

\section{Oxygen uptake by fungal spore-supplemented soil}

In various tests, oxygen uptake by soil supplemented with 1-10 mg. $\left(6 \times 10^{5}\right.$ $1.7 \times 10^{8}$ ) conidia of Fusarium solani, Helminthosporium victoriae, Glomerella cingulata or Neurospora sp. showed rapid and relatively great increases over that by non-supplemented soil (Figs. 1-5). Oxygen uptake by spore-supplemented soil was 7- to 33-fold greater than non-supplemented soil within 30 min., from 3- to 35 -fold greater in $1 \mathrm{hr}$ and 3- to 20 -fold greater in $2 \mathrm{hr}$. Subsequent differences in respiration rates to the end of experiments $\left(4-6 \frac{1}{2} \mathrm{hr}\right)$ were of a similar order. Since alkali in the centre wells of the reaction vessels might decrease $\mathrm{CO}_{2}$ concentration below those normally existing in soil and thereby affect the metabolic responses of the soil micro-organisms, some experiments were done with a $\mathrm{CO}_{2}$ buffer (Umbreit et al. 1957) in the centre well so as to maintain the flask atmosphere at $1 \%(\mathrm{v} / \mathrm{v})$ $\mathrm{CO}_{2}$. However, the respiratory responses of soil amended with $\boldsymbol{F}$. solani spores (Fig. 2) or peptone were similar in both conditions.

Unwashed fungal spores were used in some of the experiments described above. To eliminate possible contaminating nutrients from the cultures, tests were done with unwashed Neurospora conidia which were never in contact with the agar medium, and with washed conidia of Fusarium solani. Soil supplemented with $7.5 \mathrm{mg}$. $\left(1.6 \times 10^{8}\right)$ washed $F$. solani spores gave 33- and 35 -fold increases in oxygen uptake in 30 and $60 \mathrm{~min}$., respectively (Fig. 1). A lesser increase was given by $1 \mathrm{mg}$. $\left(2.1 \times 10^{7}\right)$ washed $F$. solani spores (Fig. 2). Similarly, $3.6 \mathrm{mg} .\left(1.5 \times 10^{8}\right)$ Neurospora conidia gave respective increases of 10 - and 20 -fold in 30 and $60 \mathrm{~min}$. (Fig. 5).

The increased oxygen uptake in spore-supplemented soil might be due to the respiration of the soil microflora or to the respiration of the fungal spores themselves. The relative contribution of each was difficult to assess, since the respiratory activity of fungal spores in a fungistatic condition is unknown. Sterilized soil supplemented with live fungal spores had high respiration rates, but these spores were physiologically active rather than inactive. Cycloheximide in water at 100 or $1000 \mu \mathrm{g} . / \mathrm{ml}$. was used to simulate a fungistatic medium. Conidia of Helminthosporium victoriae or Neurospora sp. did not germinate in cycloheximide solutions, but at the end of $4 \mathrm{hr}$ the spores were still viable. Respiration in spore-supplemented cycloheximide solutions was very low (Figs. 3,5 ). If these inhibited spores can be considered as metabolically similar to those in natural soil (this is by no means certain) inhibited spores in soil may also respire at a very low rate.

To rule out respiration of the added fungal spores, soil was supplemented with killed (boiled) conidia or with cell-free aqueous washings of conidia. Oxygen uptake in soil supplemented with $10 \mathrm{mg} .\left(1 \cdot 7 \times 10^{8}\right)$ boiled Glomerella cingulata conidia was 


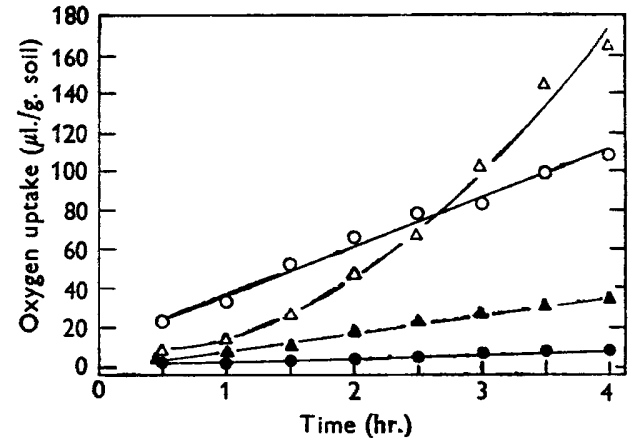

Fig. 1
Fig. 3

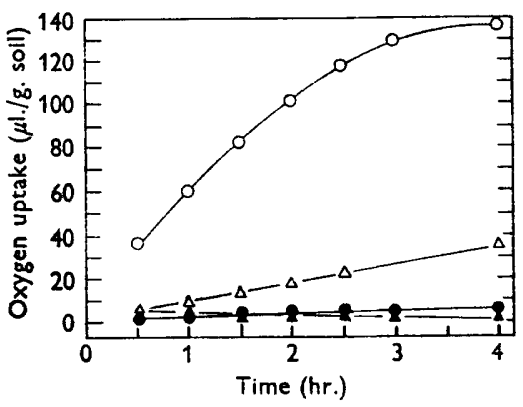

Fig. 5

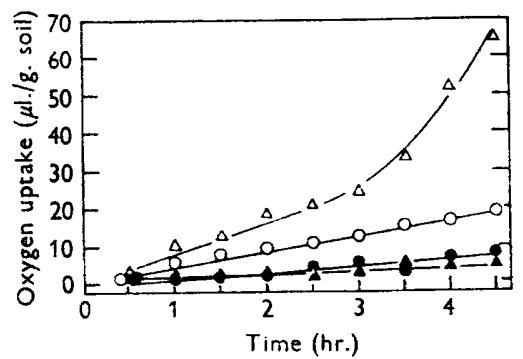

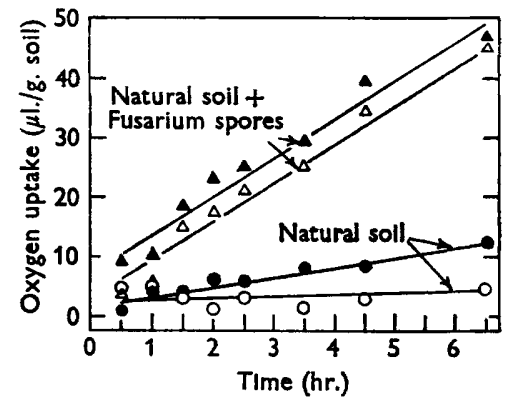

Fig. 2

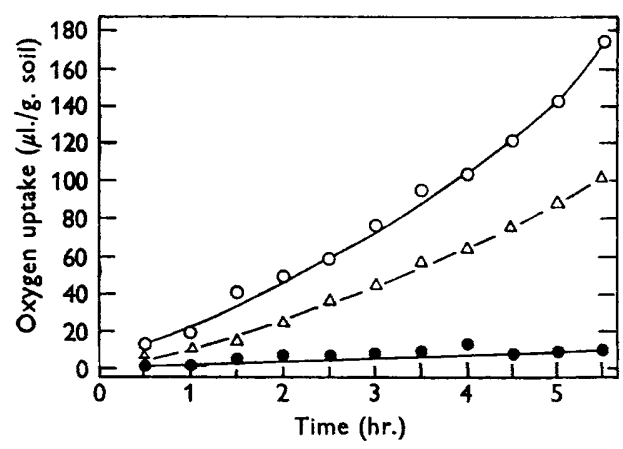

Fig. 4

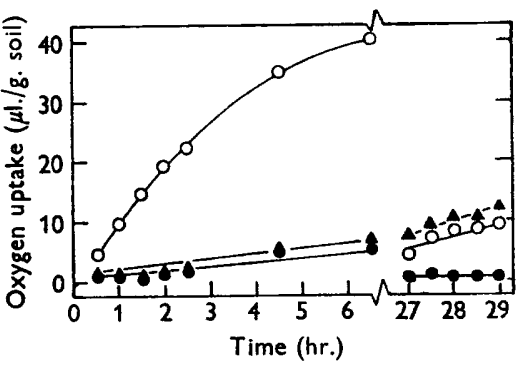

Fig. 6

Figs. 1-6. Oxygen uptake in natural Conover loam soil amended as follows (Values/g. oven-dried soil):

Fig. 1. Washed F. solani conidia (7.5 mg.; $1.6 \times 10^{8}$ spores); washings from once-washed $F$. solani conidia (1 mg.); peptone ( $20 \mathrm{mg}$.). O, Natural soil; $O$, natural soil + Fusarium spores; $\Delta$, natural soil + spore washings; $\Delta$, natural soil + peptone.

Fig. 2. Washed F. solani conidia (1 mg.; $2.1 \times 10^{7}$ spores); with $\mathrm{KOH}$ or $\mathrm{CO}_{2}$ buffer in centre well. $\bigcirc, \mathrm{A}, \mathrm{KOH}$ in centre well; $\mathrm{O}, \triangle, \mathrm{CO}_{2}$ buffer in centre well.

Fig. 3. Helminthosporium vietoriae conidia $\left(0.7 \mathrm{mg}\right.$; $6 \times 10^{5}$ spores); H. victoriae conidia $(0.7 \mathrm{mg}$.) in cycloheximide $100 \mu \mathrm{g} . / \mathrm{ml}$. solution; casein hydrolysate $(2 \mathrm{mg}$.). , Natural soil ; $O$, natural soil + Helminthosporium spores; $\Delta$, Cycloheximide + Helminthosporium spores; $\triangle$, natural soil + casein hydrolysate.

Fig. 4. Living or killed G. cingulata conidia (10 mg.; $1.7 \times 10^{8}$ spores). $O$, natural soil + Glomerella spores; $\Delta$, natural soil + boiled spores.

Fig. 5. Neurospora sp. conidia (3.6 mg.; $1.5 \times 10^{8}$ spores); Neurospora sp. conidia (3.6 mg.) in $1000 \mu \mathrm{g} . / \mathrm{ml}$. cycloheximide solution; Neurospora conidial washings (3.5 mg.). O, Natural soil; $O$, natural soil +Neurospora spores; $\Delta$, cycloheximide + Neurospora spores; $\triangle$, natural soil + spore washings.

Fig. 6. Neurospora sp. conidial washings ( $3.5 \mathrm{mg}$.); $80 \mu$ diam. glass beads (100 $\mathrm{mg}$.; $2.5 \times 10^{7}$ beads). Manometers were removed at $6 \frac{1}{2} \mathrm{hr}$, attached again at $27 \mathrm{hr}$. soil; $O$, natural soil + Neurospora washings; $\Delta$, natural soil + glass beads. 
increased fivefold over that in non-supplemented soil in $1 \mathrm{hr}$ (Fig. 4). Soil supplemented with $1 \mathrm{mg}$. of washings from previously once-washed Fusarium solani or with $3.5 \mathrm{mg}$. of washings from Neurospora conidia gave respective increases in oxygen uptake over non-supplemented soil of 7 - and 15 -fold in $1 \mathrm{hr}$ (Figs. 1, 5, 6). These spore washings would not contain nutrients leached from the culture. These results indicate that the soil microflora was stimulated by materials present in spore exudates, and suggest that living spores might have, qualitatively at least, the same effect. Increased oxygen uptake in soil supplemented with 1-2 mg. peptone or casein hydrolysate gave further evidence that the increased respiration of sporesupplemented soil was nutritional (Figs. 1, 3).

In two tests, $100 \mathrm{mg}$. $\left(2.5 \times 10^{7}\right)$ glass beads of $30 \mu$ diam. were added to soil. Respiration rates of bead-supplemented and non-supplemented soil were essentially similar during $6 \frac{1}{2} \mathrm{hr}$ incubation (Fig. 6). However, when determinations were made $20 \mathrm{hr}$ later, a 10- to 18-fold increase in oxygen uptake was shown by the beadsupplemented soil. Apparently, non-nutritive surfaces provided a stimulus for microbial activity (Park, 1956), but the increases here were slight until several hours after amendment. It was concluded that enhanced respiration of microbes in soil rapidly follows supplementation of soil with fungus spores, and that this is caused by soluble materials from the spores.

\title{
Inhibition tests with soil microbes
}

If stimulation of soil microflora by fungus spores accounts for soil fungistasis, then a causal relationship must be shown between the stimulated soil microbes and inhibition of fungus spore germination. This was tested by incubating freshly washed soil micro-organisms with fungus conidia in the absence of added nutrients. Fresh suspensions of washed mixed bacteria from soil (Table 2), washed pure cultures of bacterial isolates G-1 or G-2, or Rhizobium trifolii (Table 3), strongly inhibited the germination of conidia of Glomerella cingulata or Helminthosporium victoriae in buffer solution, or conidia of Mucor ramannianus, Penicillium frequentans, or Verticillium albo-atrum on water agar. Results were the same whether Noble (Difco) agar (a specially purified agar) or Bacto (Difco) agar was used. The degree

\section{Table 2. Inhibition of fungal spore germination by washed mixed soil bacteria}

\begin{abstract}
Suspensions of soil bacteria were prepared by incubating $10 \mathrm{mg}$. soil in $10 \mathrm{ml}$. nutrient broth for $24 \mathrm{hr}$, filtering off the soil, washing the organisms three times in cold $0.01 \mathrm{M}$ phosphate buffer (pH 7.2), then adjusting to scale reading 1.0 optical density at $500 \mathrm{~m} \mu$ with a Bausch \& Lomb Spectronic 20 colorimeter (about $2 \times 10^{8}$ organisms $/ \mathrm{ml}$.). Conidial suspensions were made from fungi grown on potato glucose agar slopes and were washed once with buffer and adjusted to $5-20 \times 10^{4}$ conidia $/ \mathrm{ml}$. Equal volumes $(0.05 \mathrm{ml}$.) of bacterial and conidial suspensions were mixed for incubation. At least 200 spores were counted for each entry. Values are a representative result from four to six tests.
\end{abstract}

\begin{tabular}{|c|c|c|c|c|c|}
\hline \multirow[b]{2}{*}{$\begin{array}{l}\text { Bacterial } \\
\text { dilution }\end{array}$} & \multicolumn{2}{|c|}{ Germination $(\%)$ in solution } & \multicolumn{3}{|c|}{ Germination (\%) on water agar } \\
\hline & $\begin{array}{l}\text { G. cin- } \\
\text { gulata }\end{array}$ & H. victoriae & $\begin{array}{c}P . \text { fre- } \\
\text { quentans }\end{array}$ & $\begin{array}{l}\text { H. raman- } \\
\text { nianus }\end{array}$ & $\begin{array}{l}\text { V. albo- } \\
\text { atrum }\end{array}$ \\
\hline $1 / 1$ & 9 & 2 & 1 & 0 & 5 \\
\hline $1 / 10$ & 26 & 38 & 0 & 4 & 20 \\
\hline $1 / 100$ & 42 & 61 & 1 & 44 & 52 \\
\hline $1 / 1000$ & 60 & 79 & 57 & 56 & 93 \\
\hline Buffer & 62 & 87 & 84 & 80 & 95 \\
\hline
\end{tabular}


of inhibition was proportional to the concentration of bacteria. At the highest concentration of mixed or pure cultures of bacteria (optical density scale reading $=1$ ), germination of all five test fungi in most tests was less than $20 \%$, whereas germination in controls was $50-65 \%$ for $G$. cingulata and $75-95 \%$ for other fungi. Germination of all five test fungi was inhibited to some degree by 1/100 dilutions of mixed soil bacteria. Germination of $\boldsymbol{P}$. frequentans and $\boldsymbol{M}$. ramannianus was inhibited by a 1/1000 dilution of mixed soil bacteria (Table 2). Germination of $G$. cingulata and $H$. victoriae was inhibited to some degree by a $1 / 100$ dilution of bacterial isolates G-1 or G-2 and by a $1 / 10$ dilution of $R$. trifolii (Table 3). In other tests, similar inhibition of germination of conidia of $G$. cingulata and $H$. victoriae was

\title{
Table 3. Inhibition of fungal spore germination by washed organisms of pure cultures of bacteria
}

\begin{abstract}
Bacteria were grown on nutrient agar slopes, collected and washed three times in cold $0.01 \mathrm{M}$-phosphate buffer (pH 7.2), then adjusted to scale reading 1.0 optical density at $500 \mathrm{~m} \mu$ with a Bausch \& Lomb Spectronic 20 colorimeter (about $14 \times 10^{8}$ organisms/ ml.). Conidial suspensions were from fungi grown on potato glucose agar slopes and were washed once with buffer and adjusted to 5-20 $\times 10^{4}$ conidia/ml. Equal volumes $(0.05 \mathrm{ml}$.) of bacterial and conidial suspensions were mixed in wells of slide plates for incubation. At least 200 spores were counted for each entry. Values are a representative result from three to five tests.
\end{abstract}

Germination (\%) of $\boldsymbol{G}$. cingulata and $\boldsymbol{H}$. victoriae conidia in presence of indicated bacterium

\begin{tabular}{|c|c|c|c|c|c|}
\hline \multirow{2}{*}{$\begin{array}{l}\text { Bacterial } \\
\text { dilution }\end{array}$} & \multicolumn{2}{|c|}{ Bacterium G-1 } & Bacterium G-2 & \multicolumn{2}{|c|}{ Rhizobium trifolii } \\
\hline & G. cingulata & H. victoriae & $\begin{array}{r}\text { G. cingulata } \boldsymbol{H} \text {. victoriae } \\
\text { Germination (\%) }\end{array}$ & G. cingulata & H. victoriae \\
\hline
\end{tabular}

$\begin{array}{lrrrrrr}1 / 1 & 2 & 2 & 18 & 2 & 28 & 1 \\ 1 / 10 & 5 & \mathbf{7} & \mathbf{2 7} & 6 & \mathbf{3 2} & 40 \\ 1 / 100 & \mathbf{2 0} & \mathbf{2 8} & \mathbf{2 8} & \mathbf{4 8} & \mathbf{4 5} & \mathbf{7 1} \\ 1 / 1000 & \mathbf{3 0} & \mathbf{8 2} & \mathbf{5 1} & \mathbf{8 6} & \mathbf{4 2} & \mathbf{7 3} \\ \text { Buffer } & \mathbf{5 1} & \mathbf{8 5} & \mathbf{5 9} & \mathbf{8 7} & \mathbf{4 7} & \mathbf{7 7}\end{array}$

obtained with washed spores of four Streptomyces isolates or with washed Bacillus subtilis. Thus, inhibition resulted from some activity of the bacteria or actinomycetes initiated after washing and which required an effective time period no longer than that for germination of the fungal spores. The speed of the inhibition was especially well shown with $H$. victoriae, which will emit a visible germ tube in 30-60 min., and will give one several times the length of the spore' in 3-4 hr. Even with this capacity for rapid germination, $\boldsymbol{H}$. victoriae was strongly inhibited in the presence of washed bacteria. The fact that the bacteria were washed three times in cold buffer solution would seem to rule out preformed staling-products of the cultures as inhibitory factors. The possibility existed, however, that metabolic products (staling-products, antibiotics, etc.) generated by the washed bacteria during incubation with the fungal spores might account for the inhibition of fungal spore germination. This was tested by applying fresh sterile (Millipore) filtrates from suspensions of mixed or pure cultures of washed bacteria to the incubating fungal spores, once or at 30-60 min. intervals throughout the germination period (Tables 4, 5). Inhibition of germination was never observed, whether the filtrate was applied to 
Table 4. Effect of sterile filtrates of washed mixed soil bacteria on germination of fungus spores

Suspensions of soil bacteria were prepared by incubating $10 \mathrm{mg}$. soil in $10 \mathrm{ml}$. nutrient broth for $24 \mathrm{hr}$, filtering off the soil, washing the organisms three times in cold $0.01 \mathrm{M}$ phosphate buffer (pH 7.2), then adjusting to scale reading 1.0 optical density at $500 \mathrm{~m} \mu$ with a Bausch \& Lomb Spectronic 20 colorimeter (about $2 \times 10^{8}$ organisms $/ \mathrm{ml}$.). Conidial suspensions were prepared from fungi grown on potato glucose agar slopes and were washed once with buffer and adjusted to 5-20 $\times 10^{4}$ conidia $/ \mathrm{ml}$. At least 200 spores were counted for each entry. Values are from one of three tests.

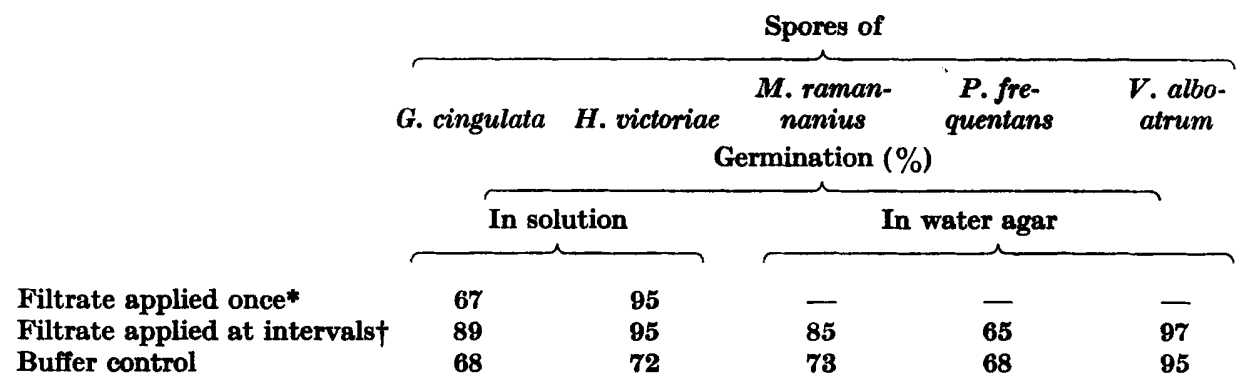

* Fresh bacterial suspension was passed through sterile $0.45 \mu$ Millipore filter. Equal volumes $(0.05 \mathrm{ml}$.) of filtrate and conidial suspension were mixed for incubation.

$\dagger$ Immediately after preparation and at $\mathbf{8 0} \mathrm{min}$. (H. victoriae) or $60 \mathrm{~min}$. (other fungi) intervals thereafter, a portion of the same bacterial suspension was passed through a sterilized $0.45 \mu$ Millipore filter, and used to replace or supplement the incubation medium.

\section{Table 5. Effect of filtrates of suspensions of roashed bacteria on germination of fungus spores}

Bacteria were grown on nutrient agar slopes, collected and washed three times in cold 0.01 M-phosphate buffer ( $\mathrm{pH} \mathrm{7.2),} \mathrm{then} \mathrm{adjusted} \mathrm{to} \mathrm{scale} \mathrm{reading} 1.0$ optical density at $500 \mathrm{~m} \mu$ with a Bausch \& Lomb Spectronic 20 colorimeter (about $14 \times 10^{8}$ organisms/ ml.). Conidial suspensions were prepared from fungi grown on potato glucose agar slopes and were washed once with buffer and adjusted to 5-20 $\times 10^{4}$ spores $/ \mathrm{ml}$. At least 200 spores were counted for each entry. Values are from one of three tests.

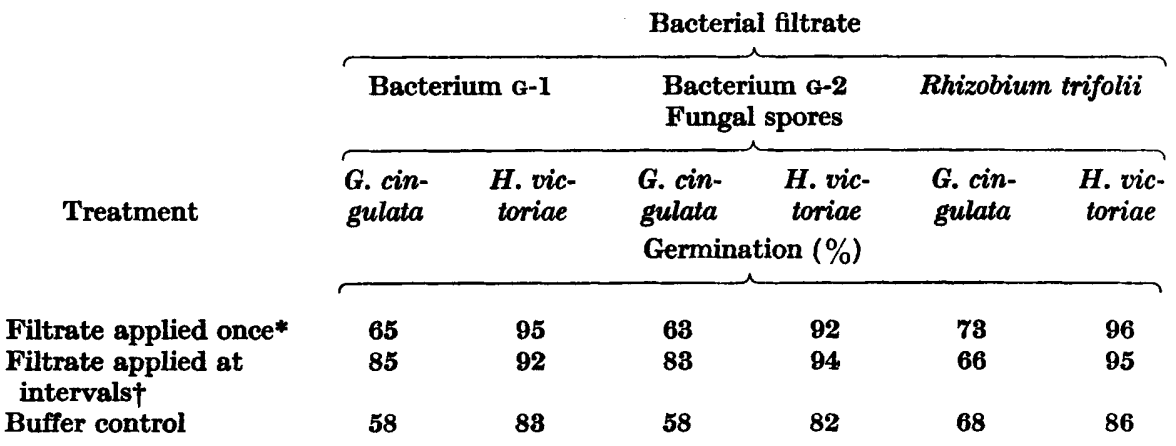

* Fresh bacterial suspension was passed through sterile $0.45 \mu$ Millipore filter. Equal volumes $(0.05 \mathrm{ml}$.) of filtrate and conidial suspensions were mixed for incubation.

$\dagger$ Immediately after preparation and at $30 \mathrm{~min}$. (H. victoriae) or $60 \mathrm{~min}$. (G. cingulata) intervals thereafter, a portion of the same bacterial suspension was passed through a sterilized $0.45 \mu$ Millipore filter, and used to replace the germination medium. 
spores in wells of slide plates or to spores on water agar. In fact, germination as well as the rate and vigour of germ tube extension was usually stimulated by these filtrates. For example, in a typical experiment, the mean length of germ tubes of $H$. victoriae in buffer was $98 \mu$, whereas, in filtrates of mixed soil bacteria applied once, it was $161 \mu$; stimulation was also observed when filtrates were applied repeatedly.

The inhibition of fungus spore germination by washed bacteria and streptomyces and the absence of inhibitory substances from filtrates of incubated suspensions of washed bacteria suggest a causal relation between microbial activity and fungal spore inhibition, and that the presence of the fungal spores was required to initiate the inhibitory action.

\section{DISCUSSION}

The results presented in this paper make three main points: (1) fungus spores, by virtue of their exudates, stimulate activity and growth of micro-organisms in soil; (2) stimulation of bacterial metabolic activity occurs quickly after placing fungal spores in soil; (3) bacterial stimulation by fungus spores apparently is causally related to inhibition of fungal spore germination. These results support the authors' previous hypothesis, namely, that soil fungistasis is caused by soil microbes activated in the vicinity of fungus spores (Lingappa \& Lockwood, 1961). It does not seem necessary to invoke the pre-existence in soil of fungistatic substances such as 'staling-products' in order to account for the inhibition of fungal growth. Some workers have reported inhibition of germination (Stover, 1958; Jackson, 1959; Dobbs \& Griffiths, 1960; Dobbs et al. 1960; Griffin, 1962b) or growth (Jefferys \& Hemming, 1953; Park, 1956; Stover, 1958) of fungi in some non-sterile aqueous extracts of soil, but soil extracts have also been reported to be non-inhibitory or even stimulatory (Dobbs et al. 1960; Hack \& Williams, 1960; Lingappa \& Lockwood, 1961). Moreover, when inhibitory soil extracts were passed through sterilizing filters or autoclaved, the inhibitory activity was usually eliminated (Park, 1956; Stover, 1958; Jackson, 1959; Dobbs \& Griffiths, 1960; Griffin, 1962b). Thus, fungal growth inhibition in non-sterile extracts might have been due to microbial activity (Jackson, 1959) rather than to fungistatic substances extracted from soil. In one case (Dobbs \& Griffiths, 1960), some inhibition of spore germination with Seitz-filtered soil extract was shown under conditions of decreased aeration; however, these authors also reported failure of unfiltered or filtered soil extracts to inhibit fungal spore germination in air.

Evidence reported in the present paper of enhancement of respiration and growth of soil microbes by water washings of fungal spores suggests that spores contain readily extractable nutrient materials. It is likely that exudation of such materials from fungal spores continues after washing. Washed Fusarium solani conidia enhanced oxygen uptake in soil supplemented with them, and second washings from $F$. solani conidia contained substances stimulatory of respiration of soil microorganisms. Conidia of Glomerella cingulata also released more material in a second washing (Richardson \& Thorn, 1962). The quantities of materials exuded by spores may be substantial. Single aqueous washings of Puccinia graminis urediospores or of Neurospora conidia each contained about $10 \%$ of the dry weight of the unwashed spores. Water extracts of conidia of Neurospora sitophila (McCallan \& Wilcoxon, 
1936; Wain \& Wilkinson, 1946) or G. cingulata (Richardson \& Thorn, 1962; Thorn \& Richardson, 1962) contained amino acids; those of $N$. sitophila also contained organic acids (Wain \& Wilkinson, 1946). These substances are readily utilizable by a variety of micro-organisms. Loss of cellular contents, including amino acids and nucleic acids, has been reported from spores treated with fungicides (Burchfield \& Storrs, 1957 ; Miller \& McCallan, 1957 ; Tröger, 1958; Sisler \& Cox, 1960; Richardson \& Thorn, 1962; Thorn \& Richardson, 1962) or antibiotics (Lowry \& Sussman, 1956; Gottlieb et al. 1961). These losses seem to represent increased exudation over that which occurs when spores are in distilled water (Miller \& McCallan, 1957; Richardson \& Thorn, 1962; Thorn \& Richardson, 1962). In some cases at least, loss of cell constituents by sublethal concentrations of fungicides did not impair germinability of spores (Burchfield \& Storrs, 1957; Miller \& McCallan, 1957). Thus, in soil, fungal spore exudates might stimulate soil microbes to produce growth-inhibitory but sublethal concentrations of antibiotics, which in turn might induce greater leakage of spore contents, thus further activating the soil microflora.

Evidence for rapid stimulation of microbes in soil by added nutrients was obtained in Warburg experiments with soil supplemented with fungus spores, spore washings or dilute nutrients. Oxygen uptake increased before the numbers of micro-organisms increased. Similar work (Rovira, 1953; Stevenson, 1956) indicated that the activity of microbes in soil can be rapidly stimulated; these workers showed that oxygen uptake in remoistened air-dried soil was several-fold higher than that of fresh soil, the increase beginning almost immediately after remoistening. The enhanced respiration was attributed to increased metabolic activity of the soil microbes, and Stevenson (1956) further showed that bacterial numbers in air-dried soil were lower than in fresh soil and did not begin to increase until at least the 3rd hour of incubation. Non-biological oxygen uptake was ruled out and a nutritional basis for the response was suggested by the presence of amino acids in water extracts of the air-dried soil, and their absence from extracts of fresh soil. Similar rapidly enhanced activity of micro-organisms has been shown in soil supplemented with glucose (Rovira, 1956), amino acids or mixtures of carbohydrates with organic acids (Katznelson \& Rouatt, 1957), and ethanol or sodium acetate (Stevenson \& Katznelson, 1958). For example, soil supplemented with dilute glucose solution maintained a sixfold higher oxygen utilization rate than non-supplemented soil when determinations were made from 30-210 min. (Rovira, 1956).

A causal relation between microbial activation by fungus spores and inhibition of spore germination is indicated by experiments in which washed bacteria prevented fungal spore germination in the absence of added nutrients. The inability of cellfree filtrates of inhibitory bacteria to effect inhibition would suggest that autolytic products, staling-products and the like were not involved.

It is not known which soil microbes are specifically involved in soil fungistasis, -or indeed whether activity resides exclusively with any special group. All of 67 isolates of actinomycetes, bacteria or fungi, whether inhibitory or not in agar-streak tests, were able to restore a level of fungistasis to sterilized soil, though some were more effective than others (Lockwood \& Lingappa, 1963). In the present work, fungal spore germination was inhibited by various mixed and pure cultures of bacteria and streptomyces. One might regard bacteria as most likely involved in mycostasis because of their short generation times and their multiplication in spore- 
supplemented soil. However, increased numbers of micro-organisms were not involved in the early enhanced activity of supplemented soil in the present work, or in experiments with remoistened air-dried soil (Stevenson \& Katznelson, 1958). Moreover, bacteria were less effective than actinomycetes and fungi in restoring fungistasis to sterilized soils (Lockwood \& Lingappa, 1963). The means by which soil microbes inhibit the germination of fungal spores in soil is not known, though most workers attribute this inhibition to some fungistatic microbial product. It is also possible that soil microbes create nutrient deficiencies in the vicinity of the spore by rapid utilization of nutrients in spore exudates which may be required for spore germination. Either of these views would be compatible with the interpretation of soil fungistasis presented herein.

Financial assistance provided by U.S. National Science Foundation Grant G-20033 is gratefully acknowledged. This work is published as Journal Article No. 3254 of the Michigan Agricultural Experiment Station.

\section{REFERENCES}

Burchfield, H. P. \& Storrs, E. E. (1957). Effects of chlorine substitution and isomerism on the interaction of s-triazine derivatives with conidia of Neurospora sitophila. Contrib. Boyce Thompson Inst. 18, 429.

Dobss, C. G. \& Griffiths, D. A. (1960). Studies in soil mycology IV. Rep. For. Comm. Lond. p. 87.

Dobss, C. G., Hinson, W. H. \& BYwater, J. (1960). Inhibition of fungal growth in soils. In Ecology of Soil Fungi, p. 130. Ed. by D. Parkinson \& J. S. Waid. Liverpool: University Press.

Gottuleb, D., Carter, H. E., Sloneker, J. H., Wu, L. C. \& Gowdy, E. (1961). Mechanisms of inhibition of fungi by filipin. Phytopathology, 51, 321.

Grifriv, G. J. (1962a). Production of a fungistatic effect by soil microflora in autoclaved soil. Phytopathology, 52, 90.

Grifrin, G. J. (1962b). Nature of Soil Fungistasis. Ph.D. Thesis. Colorado State University.

Hack, J. \& Wrlurams, P. H. (1960). The effect of certain soil treatments on Didymella stem-rot of tomatoes. II. Laboratory Investigations. Ann. appl. Biol. 48, 236.

JACKson, R. M. (1959). Soil fungistasis. Rep. Rothamst. exp. Sta. 1958, p. 71.

JefFerys, E. G. \& Hemming, H. G. (1953). Fungistasis in soils. Nature, Lond. 172, 872.

Katznelson, H. \& Rouatt, J. W. (1957). Manometric studies with rhizosphere and non-rhizosphere soil. Canad. J. Microbiol. 3, 673.

LingAPPA, B. T. \& LockwOod, J. L. (1961). The nature of the widespread soil fungistasis. J. gen. Microbiol. 26, 473.

LingaPPA, B. T. \& LockwOod, J. L. (1962). Relationship of soil microbes to the widespread soil fungistasis (Abs.). Phytopathology, 52, 739.

LockwOod, J. L. \& LiNGAPPA, B. T. (1963). Fungitoxicity of autoclaved soil inoculated with soil microflora. Phytopathology, 53, 917.

Lowny, R. J. \& Sussman, A. S. (1956). Physiology of the cell surface of Neurospora ascospores. II. Interference with dye adsorption by polymyxin. Arch. Biochem. 62, 113.

McCallan, S. E. A. \& Wilcoxon, F. (1936). The action of fungus spores on Bordeaux mixture. Contrib. Boyce Thompson Inst. 17, 151.

Mrluer, L. P. \& McCallan, S. E. A. (1957). Movement of ions and compounds in and out of fungus spores. Science, 126, 1223.

PArk, D. (1956). On the role of amendments in the biology of fungi in soil. Int. Congr. Soil Sci. 6, 23.

PARK, D. (1961). Morphogenesis, fungistasis and cultural staling in Fusarium oxysporum Snyder \& Hansen. Trans. Brit. mycol. Soc. 44, 377. 
Richardson, L. T. \& Thorn, G. D. (1962). Stimulation of spore germination and growth of Glomerella cingulata by copper and other heavy metal ions. Phytopathology, 52, 865.

Rovira, A. D. (1953). Use of the Warburg apparatus in soil metabolism studies. Nature, Lond. 172, 29.

Rovira, A. D. (1956). Plant root excretions in relation to the rhizosphere effect. III. The effect of root exudates on the numbers and activity of microorganisms in soil. Plant \& Soil, 7, 209.

Sisler, H. D. \& Cox, C. E. (1960). Physiology of fungitoxicity. In Plant PathologyAn Advanced Treatise. Ed. by J. G. Horsfall \& A. E. Dimond, vol. 2, p. 507. New York: Academic Press.

Stevenson, I. L. (1956). Some observations on the microbial activity in remoistened air-dried soils. Plant \& Soil, 8, 170.

Stevenson, I. L. \& Katzinelson, H. (1958). The oxidation of ethanol and acetate in soils. Canad. J. Microbiol. 4, 73.

Stover, R. H. (1958). Studies on Fusarium wilt of bananas. III. Influence of soil fungitoxins on behavior of $F$. oxysporum f. cubense in soil extracts and diffusates. Canad. $J$. Bot. 36, 439.

Thorn, G. D. \& Richardson, L. T. (1962). Exudate produced by Glomerella cingulata spores in presence of copper and dithiocarbamate ions. Canad. J. Bot. 40, 25.

Tröger, R. (1958). Studien zur Fungicidwirkung der Schwermetallsalze. Arch. Mikrobiol. 29, 430.

Umbreit, W. W., BurRis, R. H. \& StaufFer, J. F. (1957). Manometric Techniques, 338 pp. Minneapolis, Minn., U.S.A.: Burgess Publishing Co.

Warn, R. L. \& Wrukinson, E. H. (1946). Studies on the copper fungicides. IX. Investigations with the exudate from fungus spores. Ann. appl. Biol. 33, 401. 